\title{
A Case of Sjögren's Syndrome-Related
Pulmonary Arterial Hypertension Treated with Iloprost and Bosentan Combination Therapy
}

\author{
Iloprost ve Bosentan Kombinasyon Tedavisi Uygulanan Bir Sjögren \\ Sendromu İlişkili Pulmoner Hipertansiyon Olgusu
}

Ayşe Baha' ${ }^{1}$ Berkay Ekici², Nalan Ogan', Evrim Eylem Akpınar'

\section{Abstract}

Sïgren's syndrome (SS), which is characterized by lymphocytic infiltration of the exocrine glands, is the second most common multisystem autoimmune disease after rheumatoid arthritis. Pulmonary involvement ranges from $9 \%$ to $20 \%$ and it usually occurs as an airway disease or interstitial lung disease. Pulmonary arterial hypertension (PAH) is a very rare condition in SS. In SS-associated PAH, the functional class of patients is usually World Health Organization (WHO) Class III/IV and there is no specific treatment regimen. In addition to nonspecific medical treatment for $\mathrm{PAH}$, treatment of the underlying disease and supportive therapy are important. The aim of this manuscript was to present a case of SS-related PAH (SRP) followed under bosentan and iloprost combination therapy.

Key words: Siögren Syndrome, Pulmonary Hypertension, Combination Therapy, lloprost, Bosentan.
Özet

Siögren Sendromu (SS) ekzokrin glandların lenfositik infiltrasyonu ile karakterize, romatoid artritten sonra ikinci en sık görülen multisitem otoimmün hastalıktır. Pulmoner tutulum \%9-20 sıklıkta bildirilmiştir ve genellikle hava yolu hastalığı ya da interstisyel akciğer hastalığı şeklinde görülür. Pulmoner Arteriyel Hipertansiyon (PAH) gelişimi SS'da çok nadir bir durumdur. SS ilişkili PAH'da hastalar genellikle fonksiyonel sınıf WHO-III/IV'dür ve spesifik bir tedavi rejimi yoktur. $\mathrm{PAH}^{\prime}$ ın nonspesifik tedavisine ek olarak altta yatan hastalı̆̆ın tedavisi önemlidir. Bu yazıdaki amacımız iloprost ve bosentan kombinasyon tedavisi altında izlediğimiz bir SS ilişkili PAH (SIP) olgusunu takdim etmektir.

Anahtar Sözcükler: Siögren Sendromu, Pulmoner Hipertansiyon, Kombinasyon Tedavisi, Illoprost, Bosentan.
Pulmonary manifestations of Siören's Syndrome (SS) include airway disease, pleuritis, interstitial lung disease, and lymphoma. Although pulmonary arterial hypertension (PAH) may complicate SS, this scenario is uncommon (1). PAH is more frequently associated with other connective tissue diseases, particularly scleroderma. Only a few cases of PAH associated with SS have been reported in the literature (1) and our case is the first case of $S$ related PAH (SRP) reported from Turkey.
'Department of Pulmonary Medicine, Ufuk University Faculty of Medicine, Ankara, Turkey

${ }^{2}$ Department of Cardiology, Ufuk University Faculty of Medicine, Ankara, Turkey
'Ufuk Üniversitesi Tıp Fakültesi, Göğüs Hastalıkları Anabilim Dalı, Ankara

${ }^{2}$ Ufuk Üniversitesi Tıp Fakültesi, Kardiyoloji Anabilim Dalı, Ankara

Submitted (Başvuru tarihi): 09.11.2017 Accepted (Kabul tarihi): 11.01.2018

Correspondence (iletişim): Ayşe Baha, Department of Pulmonary Medicine, Ufuk University Faculty of Medicine, Ankara, Turkey

e-mail:dr_aysedemir@hotmail.com 


\section{CASE}

A 64-year-old male who had history of smoking (40 pack-years) and who had been followed for chronic obstructive pulmonary disease (COPD) for 4 years was admitted to the clinic with a complaint of progressive dyspnea. One year before his admission to the clinic, the patient had undergone an inferior vena cava filter placement procedure for a recurrent venous thromboembolism under warfarin treatment. Despite both COPD and rivaroxaban treatment, the patient had experienced progressive dyspnea. Echocardiography performed 1 year earlier had indicated a systolic pulmonary artery pressure (PAPsys) of $75 \mathrm{mmHg}$; following admission to our clinic, it was measured as $110 \mathrm{mmHg}$. The patient then underwent right heart catheterization. Following administration of a local anesthetic, the right internal jugular vein was cannulated using the Judkins technique. The mean pulmonary artery wedge (mPCWP) was $10 \mathrm{mmHg}$, the mean PA pressure (mPAP) was $53 \mathrm{mmHg}$, the systolic pressure (SRVP) was $73 \mathrm{mmHg}$, and the diastolic RV pressure (DRVP) was $8 \mathrm{mmHg}$, and the mean RA pressure (mRAP) was $5 \mathrm{mmHg}$. Adenosine given at an infusion rate of 50 $\mathrm{mcg} / \mathrm{kg} / \mathrm{minute}$ did not change the mean PAP and vasoreactivity was found to be negative. Lung ventilationperfusion scintigraphy revealed a low probability for pulmonary thromboembolism. Thorax computed tomography angiography (CTA) did not show any filling defect indicating a thrombus, but the diameter of the main pulmonary artery was greater than the aorta (Figure 1). A high-resolution CT revealed lower zone cystic bronchiectasis (Figure 2). Although the patient did not have xerostomia or xerophthalmia, he had high levels of antinuclear-antibody (ANA) and anti-Sjögren's-syndrome-related antigen $A$ (anti-SSA antibodies). A Schirmer test was positive. A biopsy revealed lymphocytic infiltration of the minor salivary gland, suggesting the diagnosis of Siögren's syndrome (SS). Hydroxychloroquine and iloprost treatments were started for SS and associated pulmonary arterial hypertension (PAH). The patient's dyspnea worsened after 5 months of iloprost treatment and his WHO functional status increased from III to IV. A 6-minute walking test result decreased from 230 meters to 75 meters. A pulmonary function test performed 1 year previously revealed $\mathrm{FEV} 1=920$ cc $(32 \%), F V C=1590$ cc (39\%), $\mathrm{FEV} 1 / \mathrm{FVC}=57 \%$, Diffusing capacity of the lungs for carbon monoxide (DLCO) was not measured. A new pulmonary function test revealed a mixed pattern and the DLCO was determined to be very low (FVC $=1480$ cc [36\%], FEV $1=800$ cc [25\%], FEV1/FVC: 54\%, DLCO: 18\%). A thorax CTA revealed no thrombus. PAPsys was measured as $110 \mathrm{mmHg}$ on a repeat echocardiogram. Bosentan was added to the iloprost treatment. PAPsys was measured as $64 \mathrm{mmHg}$ at the first month of combination therapy. The patient is now in clinically stable condition and is being followed up with combination therapy for PAH and hydroxychloroquine therapy for SS.

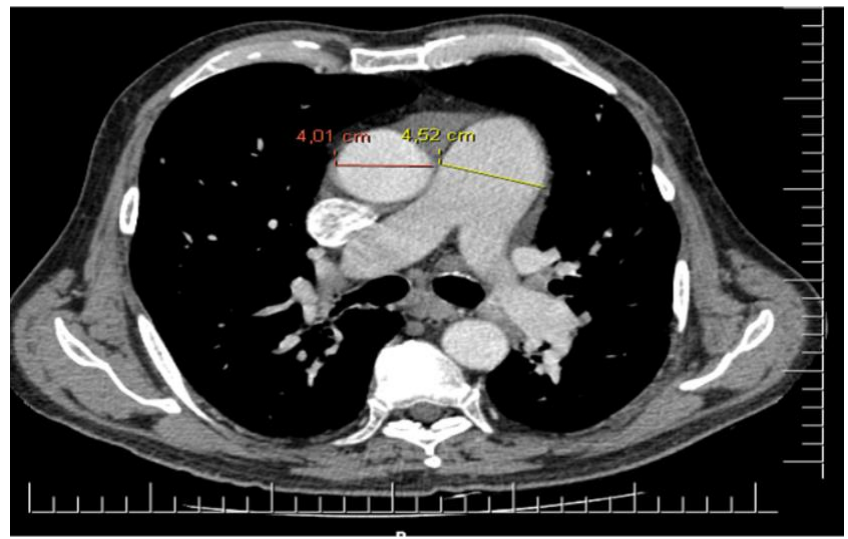

Figure 1: The diameter of the main pulmonary artery was greater than the diameter of the aorta (thorax computed tomography angiography, mediastinal section)

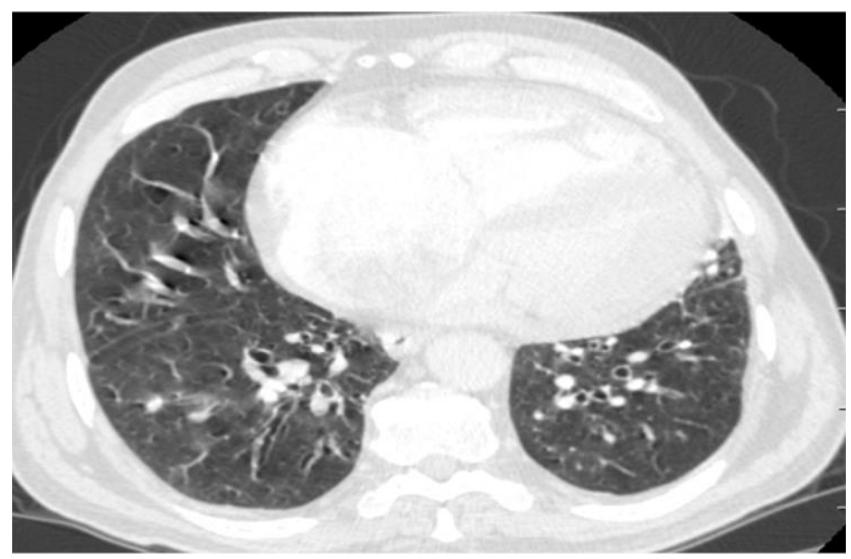

Figure 2: Bronchiectasis can be seen in the lower zones of a highresolution computed tomography image (parenchymal section)

\section{DISCUSSION}

SS is characterized by lymphocytic infiltration of the exocrine glands, and is the second most common multisystem autoimmune disease after rheumatoid arthritis (1). In SS, while middle-aged women are most often affected, men may also develop SS, typically after the age of 65 years. Almost all SS-related PAH (SRP) cases reported in the literature are female patients (2-6). Our patient is a rare male example.

Systemic manifestations of SS are vasculitis and involvement of the lungs, kidneys, and central nervous system. One of the findings in patients with SS is $\mathrm{PAH}$, but it is rare (1). Only 32 cases of SRP had been reported in the 
literature as of 2007. After 2007, patients with SS were screened for PAH and 1 case series was reported (2).

The incidence of SRP is unknown. In a recently published review it was reported that the incidence of PAH in patients with SS is rare (1). In recent years, studies have shown that connective tissue disease (CTD)-related PAH is the second leading cause of PAH (25\% of all cases). A study from China reported that the most common underlying disease among CTD-related PAH patients was systemic lupus erythematosus (49\%), followed by SS (16\%), and scleroderma (6\%) (7). In another study, it was reported that SRP accounts for almost $1 \%$ of cases of CTDrelated PAH (8).

Surprisingly, our patient did not have symptoms of SS, although he had ANA and anti-SSA antibody positivity. In the literature, there is only 1 case similar to ours reporting SRP without clinical manifestations despite serological positivity (4).

The pathogenesis of PAH in SS is not clear. However, it is thought that it results from vasculitis with prolonged vasospasm followed by structural vessel remodeling, eventually leading to irreversible thrombotic obstruction of pulmonary arterioles (9). A study indicated that systemic vasculopathy, B-cell activation, and autoimmunity are involved in the pathogenesis of SRP, supporting the vital role of immunosuppressants for the treatment of PAH in SS (2). Zhao et al. (5) reported that endothelial damage, immune complex accumulation, necrotizing vasculitis, and imbalances of endothelium-derived vasoactive molecules are also involved in the pathogenesis of SRP.

The gold standard treatment strategy for SRP has yet to be found because of rarity of the disease. These cases are being treated like other CTD-related PAH cases (2). There are many drugs targeting the underlying pathophysiological mechanisms of PAH. In addition to PAH-specific therapy, supportive treatment, as well as the treatment of the underlying disorder, is also important.

There is a report of 1 patient with SRP who was treated with long-term epoprostenol therapy (3). Launay et al. (2) examined 28 SRP cases that were reported before 2007. According to this review, 8 patients received standard PAH therapy (bosentan: 3 cases, epoprostenol: 2 cases, prostacyclin: 1 case, and 1 patient's therapy was not indicated) as first line therapy, and 3 patients received calcium channel blockers. Our case is the first report of the administration of iloprost to treat SRP. The patient's symptoms and functional status deteriorated with iloprost; therefore, bosentan was added to the therapy. The clinical status of the patient is now stable with this combina- tion therapy. Our patient is the first case of SRP treatment with the combination of iloprost and bosentan.

This case is the second reported SRP patient with ANA and anti-SSA positivity and an absence of classic SS symptoms of dry mouth and dry eye. Our case also suggests that combination therapy with iloprost and bosentan may be an alternative treatment strategy for SRP patients. Unfortunately, no specific treatment has yet been recommended for SRP. However, we suggest that supportive treatment is also crucial in these patients, as well as treatment of the underlying disease.

\section{CONFLICTS OF INTEREST}

None declared.

\section{AUTHOR CONTRIBUTIONS}

Concept - A.B., B.E., N.O., E.E.A.; Planning and Design - A.B., B.E., N.O., E.E.A.; Supervision - A.B., B.E., N.O., E.E.A.; Funding -; Materials - B.E., A.B.; Data Collection and/or Processing - B.E., A.B., N.O.; Analysis and/or Interpretation - A.B., B.E.; Literature Review - A.B., N.O., B.E.; Writing - A.B., B.E., E.E.A.; Critical Review - N.O., E.E.A.

\section{YAZAR KATKILARI}

Fikir - A.B., B.E., N.O., E.E.A.; Tasarım ve Dizayn - A.B., B.E., N.O., E.E.A.; Denetleme - A.B., B.E., N.O., E.E.A.; Kaynaklar -; Malzemeler - B.E., A.B.; Veri Toplama ve/veya İşleme - B.E., A.B., N.O.; Analiz ve/veya Yorum A.B., B.E.; Literatür Taraması - A.B., N.O., B.E.; Yazıyı Yazan - A.B., B.E., E.E.A.; Eleştirel İnceleme - N.O., E.E.A.

\section{REFERENCES}

1. Flament $T$, Bigot $A$, Chaigne B, Henique $H$, Diot $E$, Marchand-Adam S. Pulmonary manifestations of Siögren's Syndrome. Eur Respir Rev 2016; 25:110-23. [CrossRef]

2. Launay D, Hachulla E, Hatron PY, Jais X, Simonneau G, Humbert M. Pulmonary arterial hypertension: a rare complication of primary Sjogren Syndrome report of 9 new cases and review of the literature. Medicine (Baltimore) 2007; 86:299-315.

3. Fujita T1, Tanabe N, Kasahara Y, Sugiura T, Sakao S, Tatsumi K. Withdrawal of epoprostenol therapy in a patient with pulmonary hypertension associated with Siögren's syndrome. Intern Med 2014; 53:2237-40. 
4. Guerreso K, Conner EA. Possible role of anti-SSA/Ro antibodies in the pathogenesis of pulmonary hypertension. Respir Med Case Rep 2016; 17:47-9. [CrossRef]

5. Zhao J, Wang Q, Liu Y, Tian Z, Guo X, Wang $H$, et al. Clinical characteristics and survival of pulmonary arterial hypertension associated with three major connective tissue diseases: A cohort study in China. Int J Cardiol 2017; 236:432-7. [CrossRef]

6. Hwang JA, Yang TH, Lee JY, Koo DW, Choi IS, Cho SY, et al. Severe pulmonary hypertension in primary Siögren's syndrome. Korean Circ J 2013; 43:504-7. [CrossRef]
7. YJ Hao, X Jiang, W Zhou, Wang Y, Gao L, Wang $Y$ et al. Connective tissue disease-associated pulmonary arterial hypertension in Chinese patients. Eur Respir J 2014; 44:963-72. [CrossRef]

8. Condliffe R, Kiely DG, Peacock AJ, Corris PA, Gibbs JS, Vrapi $F$, et al. Connective tissue disease-associated pulmonary arterial hypertension in the modern treatment era Am J Respir Crit Care Med 2009; 179:151-7. [CrossRef]

9. Kokosi M, Riemer EC, Highland KB. Pulmonary involvement in Siögren syndrome. Clin Chest Med 2010; 31:489-500. [CrossRef] 